\title{
Screening for Hydrolytic Enzyme Production by Thermophilic Microbes Isolated from Egyptian Hot Spring
}

\author{
Maii Elsharayidi*2; ${ }^{*}$ Ahmed Dewedar ${ }^{1}$; Hesham Shafik ${ }^{2}$ and Walid Elkazzaz ${ }^{1}$ \\ ${ }^{1}$ Botany Department, Faculty of Science, Suez Canal University, Ismailia, Egypt \\ ${ }^{2}$ Botany Department, Faculty of Science, Port-Said University, Port-Said, Egypt
}

Received: $15 / 03 / 2020$

\begin{abstract}
Extreme environments like thermal springs are of considerable value as a source of thermophilic microbes, enzymes and biotechnological substances. The hot spring of Ras-Sedr is one of the Egyptian hot springs which not discovered yet. This research was carried out to isolate and screen thermophilic microbes that have the capability to produce thermostable enzymes. The sources for microbial isolation were sediment and water samples, collected from Ras-Sedr's hot spring, Ras-Sedr, Egypt. Three different medium types were used for microbial isolation. The isolates obtained were subjected for enzymatical activity. Three different enzymes, cellulase, lipase and ó-amylase, were selected to be screened by isolated strains. For cellulase activity testing, carboxy methylcellulose (CMC) agar was used as growth medium whereas tributyrin agar medium was used for lipase enzyme, while, starch agar plates were used for amylase enzyme screening. Our results showed that sediment sample harbored higher count of microbes than the water sample. Similarly, ATCC medium recorded higher thermophilic microbial count compared to the other two media used. The isolates obtained also reported a positive activity for all enzymes tested. Therefore, these promising isolates could be a source for pharmaceuticals and industrial applications.
\end{abstract}

Keywords: Hot spring, Thermophiles, Cellulase, Lipase, Amylase

\section{INTRODUCTION}

Hot springs are of great interest to the general public and to scientists because of their unusual and extreme conditions. Microbiologists around the globe are searching for hot springs interested in their chemical properties, thus creating a strong selective pressure on their microbial inhabitants (Wilkins et al., 2019). Microorganisms are essential enzyme resources, and are preferable to plant and animal sources. Currently, more than fifty percent of the enzymes used in industrial applications are from microbial origin. From the time of their discovery, extremophiles gives an excellent system for scientists. Including development under harsh conditions, researchers have been impressed by their capacity to produce industrially important substances including enzymes (Turner et al., 2007).

Enzymes from thermophilic microorganisms attracted considerable interest from industry due to their specific characteristics, such as elevated stability to $\mathrm{pH}$ changes. Reasons for targeting these enzymes include their suitability as models for investigating the thermostability of thermoenzymes and their potential as biocatalysts (Andrade et al., 1999). For decades, microorganisms have been used in the manufacturing of beer, yogurt and cheese, but the amount of prospective and realized products continues to expand in other sectors, including food industries, pharmaceuticals, paper, textile, etc. Already when they operate, many enzymes have very specific $\mathrm{pH}$ and temperature specifications. Currently, it is obvious that certain microorganisms, such as extremophiles, can generate enzymes that can survive and operate under extreme circumstances that are usually necessary for these processes (Sujatha et al., 2005). Therefore, this study was intended to isolate thermophilic microbes that have the ability to produce industrially important thermo-stable enzymes including cellulase, lipase and $\alpha$-amylase.

"Corresponding author e-mail: maiisaleh0@gmail.com

\section{MATERIALS AND METHODS}

\section{Source of Microorganisms:}

Water and sediment samples were collected from a geothermal hot spring located in Abo Swira, El Mahager road, Ras-Sedr, Egypt (Map 1). Samples were collected during summer season (July - August) in $1000 \mathrm{ml}$ bottles of sterile Pyrex. Water temperature, $\mathrm{pH}$, and EC were measured during the sampling using a portable combined $\mathrm{pH} / \mathrm{EC} /$ Temperature tester (HANNA HI98129/HI98130). Samples were maintained on ice until processing and then stored at $4^{\circ} \mathrm{C}$.Water and sediment samples were subjected to physical and chemical characterization.

\section{Isolation and purification of strains:}

Water and sediment samples were inoculated to three distinct growth media using pour plate technique. These media are ATCC, TSA and Nutrient agar. The ingredient (per 1 liter) of each medium is as follow:

ATCC medium: 697 (Thermus medium): Yeast extract $4.0 \mathrm{~g}$, Polypeptone Peptone, $8.0 \mathrm{~g} \mathrm{NaCl} 2.0 \mathrm{~g}$, Agar 30.0 g. Final pH was adjusted to 7.5 (Khalil, 2011).

TSA medium: Casein peptone (pancreatic digest) $15.0 \mathrm{~g}$, Soya peptone (papain) $5.0 \mathrm{~g}$, Sodium chloride $5.0 \mathrm{~g}$, Agar $15.0 \mathrm{~g}$. Final pH was adjusted to 7.5 (Wells-Bennik et al., 2019).

Nutrient Agar medium: Beef Extract 3.0 g, Peptone $5.0 \mathrm{~g}$, Agar15.0 g. Final pH was adjusted to $6.8 \pm 0.2$ (Wells-Bennik et al., 2019). The plates were wrapped with parafilm and kept for 24-48 $\mathrm{h}$ of incubation at $55^{\circ} \mathrm{C}$ in clean plastic bags. At the end of the incubation period, total viable count was recorded for all samples. Distinctive colonies from the culture plates were picked up and streaked on fresh medium plates and incubated at $55^{\circ} \mathrm{C}$ for $24 \mathrm{~h}$. This step is repeated for getting purified isolates. 


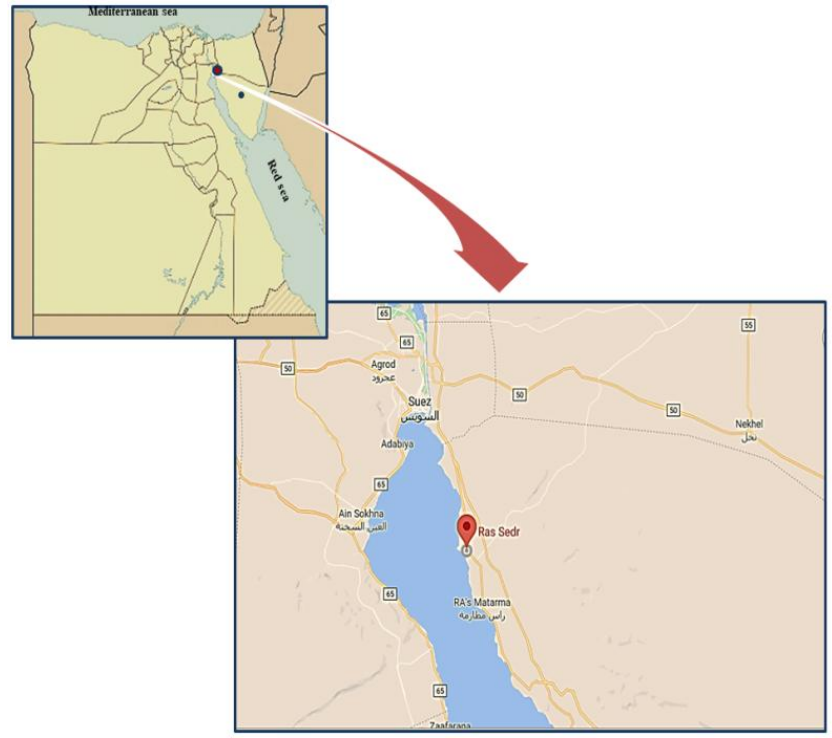

Map (1): Location of the sampling site

\section{Hydrolytic Enzymes Assessment: \\ Lipase detection:}

Thermophilic isolates were screened for Lipolytic activity on Tributyrin agar contained all common components used in NA with $1 \%$ tributyrin and incubated at $55^{\circ} \mathrm{C}$ for $24-48 \mathrm{~h}$. Positive lipaseproducing bacteria will be indicated by clear or 'halo' zones surround the colonies on tested agar following the method of Heravi et al. (2008).

\section{ó- Amylase detection:}

$\alpha$-Amylase assay was carried by culturing the thermophilic isolates on starch agar plates followed by incubation at $55^{\circ} \mathrm{C}$ for $24-48 \mathrm{~h}$. After incubation, $1 \%$ iodine solution (freshly prepared) was flooded on the starch agar plate. The presence of blue color around the growth was determined as a negative result; however, a clear zone of around the growth colonies reflected the ability of the isolates to hydrolyze starch and recorded a positive result (Hamilton et al., 1999).

\section{Cellulase detection:}

For testing the cellulolytic activity, actinobacteria were screened on carboxy methyl cellulose (CMC) agar according to the method of Ibrahim and El-diwany (2007). Cultivation medium containing: $0.1 \mathrm{~g}$ of $\mathrm{CaCl}_{2} .2 \mathrm{H}_{2} \mathrm{O}, 5.0 \mathrm{~g}$ of $\mathrm{NaCl}, 10.0 \mathrm{~g}$ of peptone, $2.0 \mathrm{~g}$ of $\mathrm{CMC}$ and $20.0 \mathrm{~g}$ of agar. The $\mathrm{pH}$ of the medium was adjusted to $\mathrm{pH} 7.0$ using $1 \mathrm{M}$ of $\mathrm{NaOH}$. The streaked plates were then incubated at $55^{\circ} \mathrm{C}$ and checked after $48 \mathrm{~h}$. The plates were flooded with iodine and the development of halo zones suggested positive activity of cellulose hydrolysis.

\section{RESULTS AND DISCUSSION}

Sediment and water samples were collected from hot spring located in Abo Swira, El Mahager road, Ras Sedr, Egypt. The physiochemical characterization of the specimen sites (Table 1) revealed that the average temperature was ranged between $80-85^{\circ} \mathrm{C}$. The $\mathrm{pH}$ of the sediment sample recorded 7.09 and 6.51 for sediment and water samples respectively. Sediments texture analysis observed to be sandy loam and organic matter content was $2.615 \%$. However, the presence of different anions, cations and heavy metals composition was measured and recorded (Table 1).

Three different culture media was used to isolate thermophilic bacteria from water and sediments samples (Table 2). Sediment sample showed more bacterial and actinobacterial counts for all three media while fewer isolates from water sample were collected. ATCC medium was the optimum for the growth of thermophilic microbiota and showed the highest number of bacterial and actinobacterial count. Sikdar et al. (2015) and Khalil (2011), also successfully used ATCC medium for thermophiles isolation. Aerial mycelia and sporulation give the colony of actinobacteria a white powdery appearance. It should be mentioned that actinobacteria isolates were fast growing, as aerial mycelium observed after only $48 \mathrm{~h}$. Kurapova et al. (2012) and Carrillo et al. (2009) also observed such rapidly growing thermophilic actinobacteria. To determine their capacity to produce hydrolytic enzymes, bacterial and actinobacterial isolates were screened to evaluate lipase, amylase and cellulase activity (Figure 2).

A total twenty four isolates were subjected to enzyme screening, the majority of the isolates showed activity for cellulase. According to Krzyśko-Łupicka et al. (2016) cellulose is the principal mass of organic matter that is degraded by soil microorganisms completely or partially. Another factor can affect the activity of cellulase is $\mathrm{pH}$ of the sample. In this study, the $\mathrm{pH}$ of sediment was 7.09; Sethi et al. (2013) detected high cellulase activity and stability in the range of neutral and alkaline pHs. On the other hand, fifteen isolates of bacteria and actinobacteria showed activity for lipase and only actinobacterial isolates showed activity for amylase. 
Table (1): Analysis of sediment and water samples

\begin{tabular}{|c|c|c|c|c|c|c|c|c|c|c|}
\hline Sample & $\begin{array}{c}\text { T.N. } \\
\%\end{array}$ & $\begin{array}{c}\text { T.P. } \\
\%\end{array}$ & $\begin{array}{c}\text { T.K. } \\
\%\end{array}$ & $\begin{array}{c}\text { O.C. } \\
\%\end{array}$ & $\begin{array}{c}\text { O.M. } \\
\%\end{array}$ & $\begin{array}{c}\text { Sand } \\
\%\end{array}$ & $\begin{array}{l}\text { Silt } \\
\%\end{array}$ & $\begin{array}{c}\text { Clay } \\
\%\end{array}$ & \multicolumn{2}{|l|}{ Tex. } \\
\hline Sediment & 0.156 & 0.0764 & 0.030 & 1.5165 & 2.615 & 66.0 & 24.0 & 10.0 & \multicolumn{2}{|c|}{ Sandy Loam } \\
\hline \multirow{2}{*}{ Sample } & \multirow{2}{*}{$\begin{array}{c}E C \\
\mathrm{dSm}^{-1}\end{array}$} & \multirow{2}{*}{ pH } & \multicolumn{4}{|c|}{ Cations meql-1 } & \multicolumn{4}{|c|}{ Anions meql-1 } \\
\hline & & & $\mathrm{Ca}^{2+}$ & $\mathrm{Mg}^{2+}$ & $\overline{\mathrm{Na}^{+}}$ & $\overline{\mathbf{K}^{+}}$ & $\mathrm{Cl}^{-}$ & $\mathrm{HCO}_{3}{ }^{-}$ & $\mathrm{SO}_{4}{ }^{2-}$ & $\mathrm{CO}_{3}{ }^{2-}$ \\
\hline Water & 7.16 & 6.51 & 34.6 & 12.4 & 31.3 & 1.70 & 48.5 & 3.00 & 28.5 & 0.00 \\
\hline Sediment & 5.15 & 7.09 & 24.4 & 8.60 & 18.5 & 1.50 & 33.5 & 1.50 & 18.0 & 0.00 \\
\hline Sample & $\begin{array}{c}\mathrm{Cu} \\
\mathrm{mg} / \mathrm{l}\end{array}$ & \multicolumn{2}{|c|}{$\begin{array}{c}\mathrm{Zn} \\
\mathrm{mg} / \mathrm{l}\end{array}$} & $\begin{array}{c}\mathrm{Mn} \\
\mathrm{mg} / \mathrm{l}\end{array}$ & \multicolumn{2}{|c|}{$\begin{array}{c}\mathrm{Co} \\
\mathrm{mg} / \mathrm{l}\end{array}$} & $\begin{array}{c}\mathrm{Pb} \\
\mathrm{mg} / \mathrm{l}\end{array}$ & \multicolumn{2}{|l|}{$\begin{array}{c}\mathrm{Fe} \\
\mathrm{mg} / \mathrm{l} \\
\end{array}$} & $\begin{array}{c}\mathrm{Cd} \\
\mathrm{mg} / \mathrm{l} \\
\end{array}$ \\
\hline Water & ND & \multicolumn{2}{|c|}{0.0466} & 0.414 & \multicolumn{2}{|c|}{ ND } & ND & \multicolumn{2}{|l|}{0.442} & ND \\
\hline Sediment & ND & \multicolumn{2}{|c|}{11.360} & 90.260 & \multicolumn{2}{|c|}{ ND } & ND & 379.6 & & ND \\
\hline \multirow{2}{*}{ Sample } & \multicolumn{5}{|c|}{ D.O (mg/l) } & \multirow{2}{*}{\multicolumn{2}{|c|}{$\begin{array}{l}\text { B.O.D. } \\
\text { (mg/l) }\end{array}$}} & \multirow{2}{*}{\multicolumn{3}{|c|}{$\begin{array}{l}\text { C.O.D. } \\
\text { (mg/l) }\end{array}$}} \\
\hline & \multicolumn{3}{|c|}{ Before incubation } & \multicolumn{2}{|c|}{ After incubation } & & & & & \\
\hline Water & \multicolumn{3}{|c|}{13.4} & \multicolumn{2}{|l|}{12.0} & \multicolumn{2}{|r|}{1.40} & \multicolumn{3}{|c|}{2.26} \\
\hline
\end{tabular}

Table (2): Total actinobacterial and bacterial counts represented in mean \pm SE of colony forming unit (CFU) in gram or milliliter of sediment and water samples, respectively

\begin{tabular}{|c|c|c|c|c|c|c|}
\hline \multirow{4}{*}{ Samples } & \multicolumn{6}{|c|}{$\begin{array}{c}\text { Total microbial count } \\
(\text { Mean } \pm \text { SE })\end{array}$} \\
\hline & \multicolumn{6}{|c|}{ Medium Used } \\
\hline & \multicolumn{2}{|c|}{ ATCC } & \multicolumn{2}{|c|}{ NA } & \multicolumn{2}{|c|}{ TSA } \\
\hline & Actinobacteria* & Bacteria $^{\dagger}$ & Actinobacteria* & Bacteria $^{\dagger}$ & Actinobacteria* & Bacteria $^{\dagger}$ \\
\hline $\begin{array}{l}\text { Sediment } \\
\mathrm{CFU} / \mathrm{g}\end{array}$ & $59.5 \pm 3.5^{\mathrm{a}}$ & $110 \pm 1.53^{\mathrm{a}}$ & $10 \pm 0.58^{\mathrm{c}}$ & $30 \pm 1.53^{\mathbf{c}}$ & $20 \pm 1.52^{b}$ & $50 \pm 1.15^{\mathrm{b}}$ \\
\hline $\begin{array}{l}\text { Water } \\
\text { CFU/ml }\end{array}$ & $3.0 \pm 0.58$ & $6.0 \pm 0.58$ & $0.0 \pm 0.0$ & $1.0 \pm 0.0$ & $1.0 \pm 0.0$ & $2.0 \pm 0.58$ \\
\hline
\end{tabular}

*Columns with different Letter are significantly different for actinobacterial count per sediment sample

${ }^{\dagger}$ Columns with different Letter are significantly different for bacterial count per sediment sample

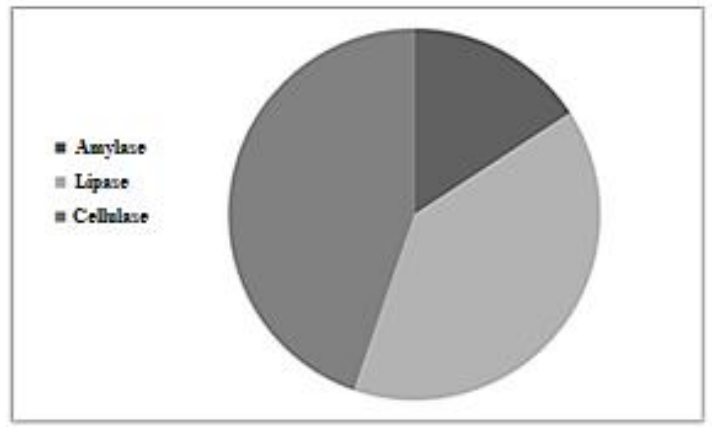

Figure (2): Enzymes activity evaluation of the isolated thermophiles

The ability of isolates for cellulase production was indicated by producing a clear zone in the presence of iodine solution staining (Figure 3). These isolates showed the ability to use carboxy methyl cellulase (CMC) as their primary source of carbon. Maki et al. (2011) performed a similar experiment for screening and identification of cellulase-producing bacteria.

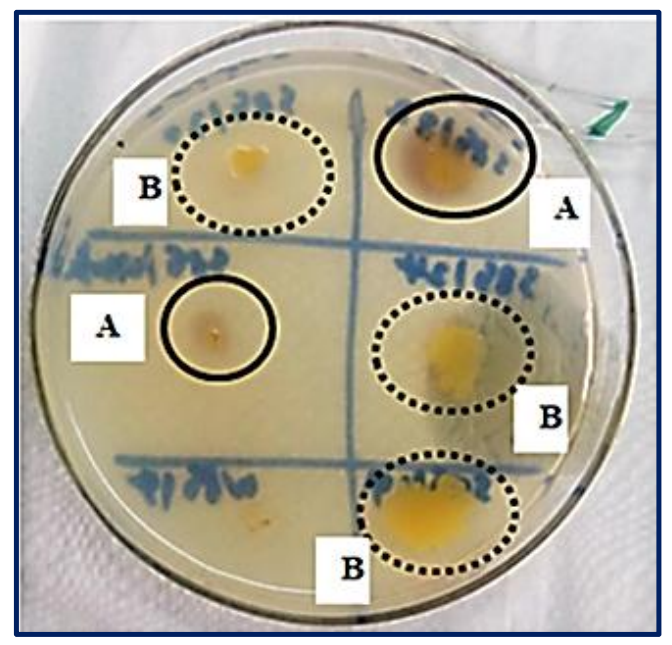

Figure (3): Cellulatic activity by isolated strains; A, represents a negative activity of cellulose enzyme by one of the isolate; $\mathrm{B}$, represents cellulase-producing isolates which showing hallo zone around the screened colonies 
In their study, they found that iodine solution was quick and effective in detecting many positive cellulase producing bacteria from broad range of samples. In similar study done by Norashirene et al. (2014) also used CMC agar plates and iodine solution staining to evaluate cellulase producing thermophiles isolated from hot spring. In general, nineteen of our isolates obtained; in this study, showed a powerful cellulase activity.

Meanwhile, for screening thermostable $\alpha-$ amylase, actinobacterial isolates obtained showed activity at $55^{\circ} \mathrm{C}$ in which the clearance of halos zones around the growth indicated the enzymatic activities (Figure 4). The halos zones were different in sizes; which revealed the different intensity of enzyme produced by the screened isolates. Selection of the powerful isolates will be promising for industrial application. Similar result was reported by (Sen et al., 2010) in which they reported different enzyme activity by different isolates.

In this study, actinobacterial and bacterial isolates were identified as powerful degrader of lipid and showed clear zones on tributyrin agar plate at $55^{\circ} \mathrm{C}$ (Figure 5). The clearance halo around the colonies was generated by tributyrin hydrolysis by isolate-based extracellular lipase production. This result is in confirmation with the data recorded by Lokre and Kadam (2014).

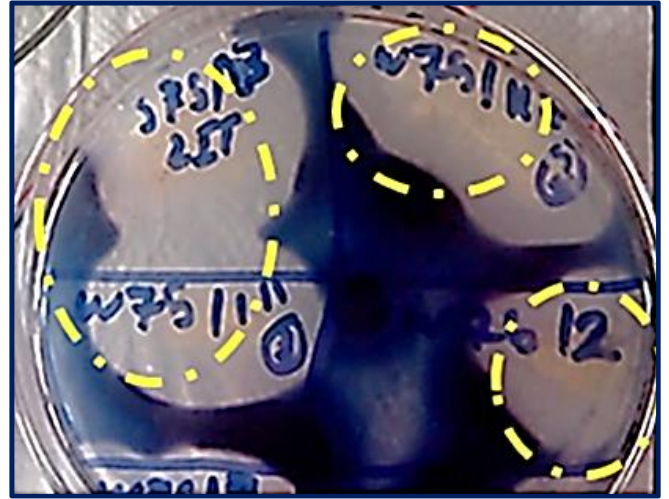

Figure (4): $\alpha$-amylase activity of different actinobacterial isolates. The activity was recorded at

$55^{\circ} \mathrm{C}$ and represented by hallo zone around the screened colonies

Despite the utility of enzymes which have thermostability in molecular biological techniques, it is not also surprising that these have also been proposed as powerful tools for industrial and commercial catalysis (Vieille and Zeikus, 2001). Cellulases are important in the fruit, beverage, fiber, paper and pulp industries, along with agriculture and other research purposes (Cavaco-Paulo, 1996; Islam and Roy, 2018). For many industries, amylase and lipase are useful, such as detergent, milk, clothing, pharmacy, and many dairy products (Patnala et al., 2016; Hussain et al., 2013).

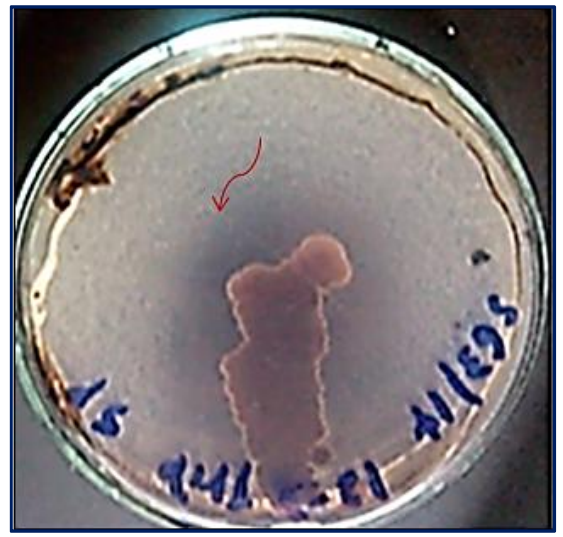

Figure (5): Lipase enzyme activity showing positive strain lipase-producers Activity represented by hallo zone around the colonies of screened isolates (arrow)
Therefore, our novel actinobacteria isolates and their industrially important enzymes (cellulase, $\alpha$ amylase and lipase) will influence the effective productivity and achieve the necessities of industries. However, the specific metabolic pathways in these actinobacteria are in need for further study to optimize these enzyme productions for maximum expanding pharmaceutically, agriculturally, and biotechnologically multifarious applications.

\section{Conclusion \& Recommendations:}

The thermophiles which studied through the current work have the ability to produce useful thermostable enzymes of industrial significance. Ras-
Sedr' shot spring considered a prospective source of economically significant microorganisms which needs more studies to explore more novel isolates with capability for more enzymes production. Consequently, further researches should be carried for such area.

\section{REFERENCES}

Ibrahim, A. S. S. and A. I. El-diwany (2007). Isolation and identification of new cellulases producing thermophilic bacteria from an Egyptian hot spring and some properties of the crude enzyme. Australian Journal of Basic and Applied Sciences, 1(4): 473-478. 
Andrade, C. M., N. Pereira Jr and G. Antranikian (1999). Extremely thermophilic microorganisms and their polymer-hidrolytic enzymes. Revista de Microbiologia, 30(4): 287-298.

Cavaco-Paulo, A. (1998). Mechanism of cellulase action in textile processes. Carbohydrate Polymers, 37(3): 273-277.

Carrillo, L., M. B. Ahrendts and M. J. Maldonado (2009). Alkalithermophilic actinomycetes in a subtropical area of Jujuy, Argentina. Revista Argentina de microbiologia, 41(2): 112-116.

Heravi, K. M., F. Eftekhar, B. Yakhchali and F. Tabandeh (2008). Isolation and identification of a lipase producing Bacillus sp. from soil. Pakistan Journal of Biological Sciences, 11(5): 740-745.

Hamilton, L. M., C. T. Kelly and W. M. Fogarty (1999). Production and properties of the raw starch-digesting $\alpha$-amylase of Bacillus sp. IMD 435. Process Biochemistry, 35(1-2): 27-31.

Hussain, I., F. Siddique, M. S. Mahmood and S. I. Ahmed (2013). A Review of the Microbiological Aspect of $\alpha$-amylase Production. International Journal of Agriculture \& Biology, 15(5): 1029-1034.

Islam, F. and N. Roy (2018). Screening, purification and characterization of cellulase from cellulase producing bacteria in molasses. BMC research notes, 11(1): 434-445.

Khalil, A. (2011). Screening and characterization of thermophilic bacteria (lipase, cellulase and amylase producers) from hot springs in Saudi Arabia. Journal of Food, Agriculture and Environment, 9(2): 672-675.

Kurapova, A. I., G. M. Zenova, I. I. Sudnitsyn, A. K. Kizilova, N. A. Manucharova, Z. H. Norovsuren and D. G. Zvyagintsev (2012). Thermotolerant and thermophilic actinomycetes from soils of Mongolia desert steppe zone. Microbiology, 81(1): 98-108.

Kurapova, A. I., G. M. Zenova, I. I. Sudnitsyn, A. K. Kizilova, N. A. Manucharova, Z. H. Norovsuren and D. G. Zvyagintsev (2012). Thermotolerant and thermophilic actinomycetes from soils of Mongolia desert steppe zone. Microbiology, 81(1): 98-108.

Wilkins, L. G., C. L. Ettinger, G. Jospin and J. A. Eisen (2019). Metagenome-assembled genomes provide new insight into the microbial diversity of two thermal pools in Kamchatka, Russia. Scientific reports, 9(1): $1-15$.

Lokre, S. S. and D. G. Kadam (2014). Screening of thermostable lipase producers from alkaline lake. Int. J. Curr. Microbiol. App. Sci, 3(11): 240-245.

Krzyśko-Łupicka, T., Kręcidło, Ł., \& Kręcidło, M. (2016). The comparison of cellulolytic activity of the modified soil treated with roundup. Chemistry-Didactics-EcologyMetrology, 21(1-2): 133-139.

Maki, M. L., M. Broere, K. T. Leung and W. Qin (2011). Characterization of some efficient cellulase producing bacteria isolated from paper mill sludges and organic fertilizers. International journal of biochemistry and molecular biology, 2(2): 146-154.

Norashirene, M. J., Y. Zakiah, S.. Nurdiana, I. N. Hilwani, M. S. Khairiyah and M. M. Arif (2014). Identification of CelluloseHydrolytic Thermophiles Isolated from $\mathrm{Sg}$. Klah Hot Spring Based On 16S rDNA Gene Sequence. World Acad Sci Eng Technol Int J Biol Biomol Agric Food Biotechnol Eng, 8(9): 1041-1044.

Patnala, H. S., U. Kabilan, L. Gopalakrishnan, R. M. D. Rao and D. S. Kumar (2016). Marine fungal and bacterial isolates for lipase production: a comparative study. In Advances in food and nutrition research (Vol. 78, pp. 71-94). Academic Press.

Sujatha, P., K. B. Raju and T. Ramana (2005). Studies on a new marine streptomycete BT-408 producing polyketide antibiotic SBR-22 effective against methicillin resistant Staphylococcus aureus. Microbiological Research, 160(2): 119-126.

Sen, S. K., S. K. Mohapatra, S. Satpathy and G. T. Rao (2010). Characterization of hot water spring source isolated clones of bacteria and their industrial applicability. International Journal of Chemical Research, 2(1): 1-7.

Sethi, S., A. Datta, B. L. Gupta and S. Gupta (2013). Optimization of cellulase production from bacteria isolated from soil. . Int Scholarly Res Notices (ISRN) biotechnology, 8: 125132.

Sikdar, A., M. Raziuddin and K. K. Gupta (2015). Isolation and characterization of thermophilic bacteria of a hot water spring source, Balbal. Int J Adv Res Biol Sci, 2(5): 106-111.

Turner, P., G. Mamo and E. N. Karlsson (2007). Potential and utilization of thermophiles and thermostable enzymes in biorefining. Microbial cell factories, 6(1):1-23.

Vieille, C. and G. J. Zeikus (2001). Hyperthermophilic enzymes: sources, uses, and molecular mechanisms for thermostability. Microbiol. Mol. Biol. Rev., 65(1): 1-43.

Wells-Bennik, M. H., P. W. Janssen, V. Klaus, C. Yang, M. H. Zwietering and H. M. Den Besten (2019). Heat resistance of spores of 18 strains of Geobacillus stearothermophilus and impact of culturing conditions. International journal of food microbiology, 291: 161-172. 


\title{
فحص الميكروبات المعزولة من الينابيع الساخنة المصرية لإنتاج إنزيمات محبة للحرارة
}

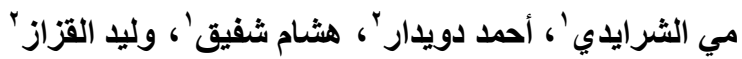

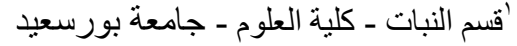 \\ كقسم النبات ـ كلية العلوم - جامعة قناة السويس
}

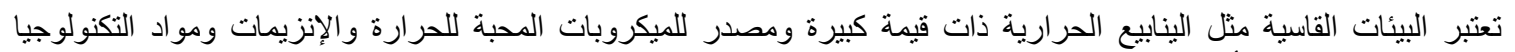

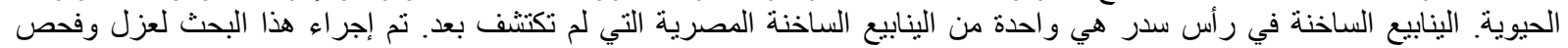

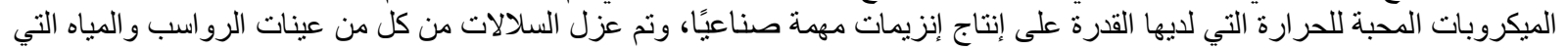

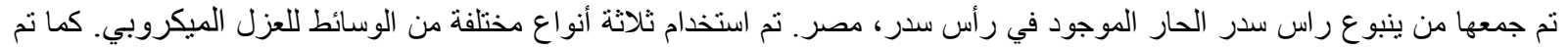

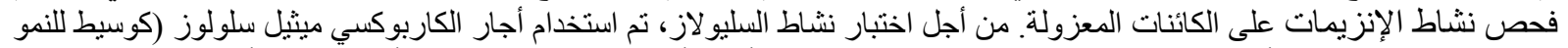

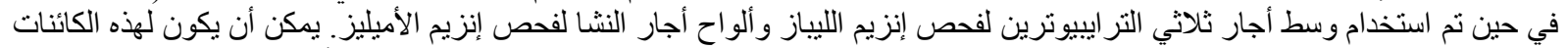

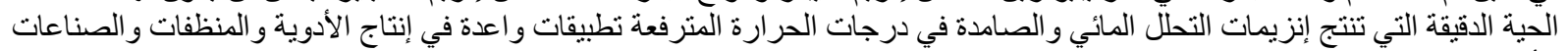
الأخرى. 